\title{
The Relationship between Abdominal Muscle and Legs Power with Turning Time on 100 Meters Free Style Swimming
}

\author{
Reza Herdiyansyah, Sandey Tantra Paramitha \\ Program Studi Ilmu Keolahragaan, Departemen Pendidikan Kesehatan dan Rekreasi \\ Universitas Pendidikan Indonesia \\ Bandung, Indonesia \\ reza_herdiyansyah@ymail.com
}

\begin{abstract}
The study was aimed to investigate the relationship between abdominal muscle and legs power with the return time on 100 meters free style swimming. The study was set as a descriptive correlation study that involved 10 members of UKM Aquatic BS UPI by using purposive sampling technique. Measurement tool to measure the power of abdominal muscle is sit up test in 30 seconds, meanwhile legs power was tested by force flat form tool and by measuring return time by using stopwatch. Based on the statistical analysis, it was revealed that there is a negative relationship between abdominal muscle power with the return time with significant value $0.01<0.05$ (Ho is rejected). In addition, there is also a negative significant relationship between legs power with return time on 100 meters free style swimming with significant value $0.000<0.05$ (Ho is rejected). The effects of abdominal muscle and legs power to swimming return time is up to $88.1 \%$, while the rest $11,9 \%$ is affected by other variables.
\end{abstract}

Keywords-abdominal muscle power; legs power; free style swimming return time

\section{INTRODUCTION}

In joining exercise or a race, swimmers aren't only required to master swimming techniques well, but they are also required to do starting up, turning, and also finishing techniques correctly. There are many swimmers who failed in winning the race because they're lack of starting and turning techniques. As important as starting technique, turning is included in a series of swimming race techniques that plays important role to make great achievement [1].

From the observation that was conducted in UKM Aquatic Bumi Siliwangi UPI, it was revealed that swimmers tend to have problems in their free style swimming turning time. They tend to be late in making turning time. This problem may lead to their achievement as swimmers in UKM Aquatic BS UPI.

Turning technique plays significant role in a swimming race or exercise because the distance of swimming is not equal to the size of the pool. It will be better for swimmers to make return by using the least energy without experiencing many obstacles in their rhyme and style of swimming [2].
Froncrowl tumble turn is the fastest turn in free style swimming that can be so helpful in swimming race due to its ability to help swimmers upgrade their time in finishing the race [1]. The researcher views that Dynamic signature for tumble turn performance may be affected by abdominal muscle and legs power. By having good abdominal muscle power, a swimmer will have a good balance that is centred on stomach and hips area that will affect the feed of turning time. The same view is given to legs power, in which a good legs power will help swimmer to make a good turning technique that lead to produce far off glide.

Some relevant studies dealing with those two physical conditions were conducted by Kiki Puspita Sari [3] and Sri Murjoko [4]. Sari's study revealed that there is significant effect of abdominal muscle power to the swimming speed of butterfly swimming style athletes in Makassar. Having the same sound, Murjoko also found a relationship between legs power with the chest style swimming speed [4].

Based on the explanation above, the study is conducted to investigate swimming speed that is related particularly to some physical conditions. It is expected that the results can be used by coach to analyse athletes' swimming speed and to evaluate the exercise process to improve athletes' performance and achievement.

\section{METHODS}

The study was conducted by using descriptive correlation study. The sample of population that were involved in the study is 20 active members of UKM Aquatic Bumi Siliwangi UPI who have mastered turning technique in free style swimming. From the population, 10 members were then purposively selected to meet the requirement of the study. Some of the requirements to be sample of study cover the following: a) sample is a member of UKM Aquatic BS UPI, b) sample has adequate knowledge and technique to make turning move in free style swimming, c) sample has experience of joining a swimming race.

In collecting data, some instruments that were employed are abdominal muscle test through sit up test by using mattress, pens and notes [5]. 


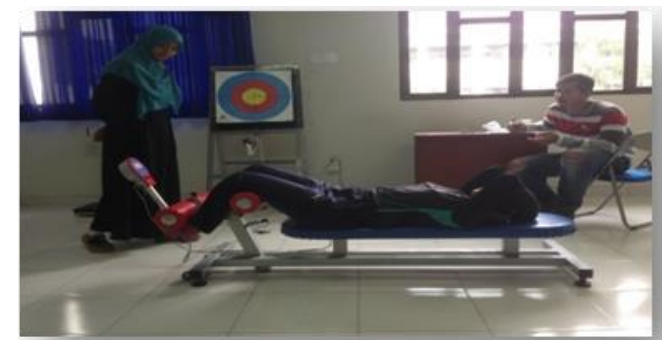

Fig. 1. Sit-ups test.

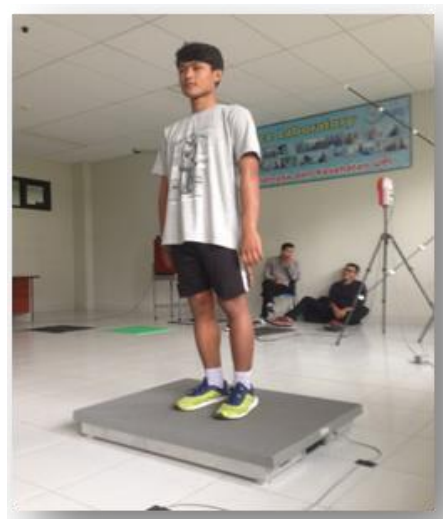

Fig. 2. Legs power test by using force flatform.

In order to test turning time, a turning time test was also conducted by following a series of Froncrowl tumble turn that cover: approaching step, turning step, pushing off step, gliding step, and pulling out step [6]. The tool that was used is stopwatch.

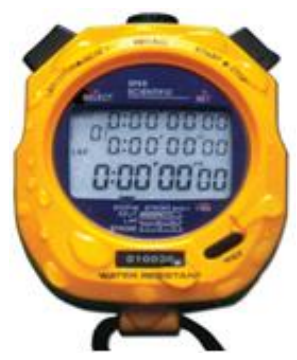

Fig. 3. Stopwatch. test:

The following figure describes the design of turning time

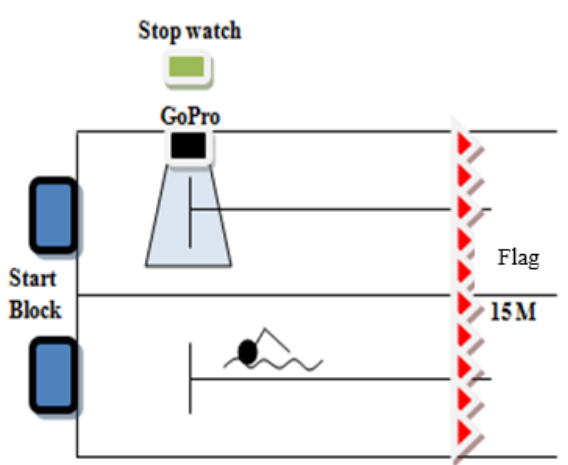

Fig. 4. Design of Returing time test.

\section{RESULTS AND DISCUSSION}

Results from a series of physical test can be described as follows:

TABLE I. RESULTS OF TESTS

\begin{tabular}{|l|l|l|l|l|l|}
\hline & $\boldsymbol{N}$ & \multicolumn{1}{|c|}{ Min } & \multicolumn{1}{|c|}{ Max } & Mean & \multicolumn{1}{|c|}{ Std. Dev } \\
\hline Legs Power & 10 & 37 & 69 & 52.10 & 10.25 \\
\hline $\begin{array}{l}\text { Abdominal } \\
\text { muscle power }\end{array}$ & 10 & 13 & 30 & 23.20 & 5.32 \\
\hline Turning time & 10 & 3 & 6 & 4.70 & 1.16 \\
\hline
\end{tabular}

It can be seen from the table that the average score of sit up test is 23,30 with standard of deviation 5,32 , the average score of legs power test is 52,10 with standard of deviation 10,25 , and the average score of turning test is 4,70 with standard of deviation 1,16 .

Meanwhile, data normality test was also conducted by using One Sample Kolmogorov Smirnov test. The data can be considered normal when sig value (p) $>0.05$ and it is not considered normal when sig value $(\mathrm{p})<0.05$.

\section{TABLE II. NORMALITY TEST}

\begin{tabular}{|l|l|l|l|l|}
\hline & $\begin{array}{l}\text { Kolmogoro } \\
\text { v-Smirnov } \\
\mathbf{Z}\end{array}$ & $\begin{array}{c}\text { Asymp. } \\
\text { Sig. (2- } \\
\text { tailed) }\end{array}$ & \multicolumn{1}{|c|}{ Details } & Conclusion \\
\hline $\begin{array}{l}\text { Turning } \\
\text { time }\end{array}$ & 0.639 & 0.809 & $\begin{array}{l}\text { Ho is } \\
\text { accepted }\end{array}$ & $\begin{array}{l}\text { Normal } \\
\text { Data }\end{array}$ \\
\hline $\begin{array}{l}\text { Abdominal } \\
\text { muscle } \\
\text { power }\end{array}$ & 0.418 & 0.995 & $\begin{array}{l}\text { Ho is } \\
\text { accepted }\end{array}$ & $\begin{array}{l}\text { Normal } \\
\text { Data }\end{array}$ \\
\hline Legs power & 0.376 & 0.999 & $\begin{array}{l}\text { Ho is } \\
\text { accepted }\end{array}$ & $\begin{array}{l}\text { Normal } \\
\text { Data }\end{array}$ \\
\hline
\end{tabular}

Kolmogorov Smirnov Z normality test data analysis shows that score of turning time 0.639 with significant value $0.809>$ 0.05 , therefore Ho is accepted and it can be concluded that the data are normally distributed. Showing the same result, the score of abdominal muscle score and legs power score are respectively 0.418 with significant value $0.995>0.05$ and 0.376 with significant value $0.999>0.05$ for legs power. Thus, it can also be concluded that the data has been normally distributed (score $\mathrm{p}=0.441>0.05)$

TABLE III. CORRELATION TEST

\begin{tabular}{|l|l|l|}
\hline \multicolumn{2}{|c|}{ Test } & Turning time \\
\hline \multirow{2}{*}{$\begin{array}{l}\text { Abdominal } \\
\text { muscle power }\end{array}$} & Pearson correlation & -0.762 \\
\cline { 2 - 3 } & Sig. & 0.010 \\
\hline \multirow{3}{*}{ Legs power } & Pearson correlation & -0.903 \\
\cline { 2 - 3 } & Sig. & 0.000 \\
\hline
\end{tabular}

The statistical data analysis shows that correlation coefficient between abdominal muscle power and turning time in 100 meters free style swimming is $-0.762, \mathrm{p}=0.010<0.05$, thus Ho can be rejected which indicates that there is a negative and significant relationship between abdominal muscle power and turning time in 100 meters free style swimming. The 
bigger abdominal muscle power, the least (faster) time made when making turn, and vice versa, the least abdominal muscle power a swimmer has, the longer (slower) the turning time made. In addition, it can also be seen from the table that correlation coefficient between legs power and turning time is $r$ $=-0.903, \mathrm{p}=0.000<0.05$, therefore Ho is also rejected. This implies that there is a negative and significant relationship between swimmers' legs power with their turning time in free style swimming. The higher the legs power, the least time made in making turn / the faster the turning time and vice versa.

Coefficient $\mathrm{R}$ determination test was then made to find out the degree of correlation between independent and dependent variables. Before conducting regression test, the data normality and correlation should be tested. Regression test can be done when the data have been normally distributed and are correlated one to another.

TABLE IV. DETERMINATION TEST OF COEF. R

\begin{tabular}{|l|c|c|}
\hline \multicolumn{1}{|c|}{ Test } & R & \multicolumn{1}{c|}{ R Square } \\
\hline Abdominal muscle power & 0.762 & 0.581 \\
\hline Legs power & 0.903 & 0.816 \\
\hline $\begin{array}{l}\text { Abdominal muscle power and } \\
\text { legs power }\end{array}$ & 0.942 & 0.888 \\
\hline
\end{tabular}

The table above shows that abdominal muscle power effects is $58.1 \%$ to the turning time, while the rest $41,9 \%$ is affected by other factors. In addition, legs power effects on turning time is $81.6 \%$, and $18.4 \%$ may be affected by other variables. Meanwhile, the effects of abdominal muscle power and legs power at the same time to turning time is up to $88.1 \%$, and $11.9 \%$ can be affected by other variables.

The discussion part explains the results of the study and problems that are faced in conducting the study. The finding of the study shows that there is a negative and significant relationship between abdominal muscle power and legs power with turning time in free style swimming (sig. value $0.010<$ 0.05). Abdominal muscle power has relationship with turning time as when someone has good abdominal muscle power, the athlete will be able to move their body faster. This finding is in accordance with Harsono who said that power is an important component in sports to strengthen the physical condition in general [7]. Physical power is a driving force to do many activities, plays role to protect athlete from being injured, and to support a more efficient physical condition.

It was also found by the study that legs power also has a negative and significant relationship with turning time in free style swimming (sig. value $0.000<0.05$ ). When an athlete has good legs power, he manages to move their body fast and able to glide far. This is in line with Harsono who asserts that "power consists of two components namely power and speed" [7]. Speed is referred to quality someone has since s/he was born that may be upgraded a little though regular exercise. Meanwhile, power can be increased by the improvement of muscle power. Power itself is the result of power that is multiplied with speed divided by time.

\section{CONCLUSION}

Based on the finding of the study, it can be concluded that there is a negative and significant relationship between abdominal muscle power and leg power with turning time in 100 meters free style swimming.

\section{IMPLICATION}

It is expected that this study can be beneficial to the related parties, especially in swimming sport. This study also needs to be developed so as to give more benefits for the achievement of sports in general, and in swimming in particular.

\section{RECOMMENDATION}

The finding of the study implies that athletes are recommended to optimize their physical condition since they play dominant role on turning technique in free style swimming. They are also expected to practice harder since swimming is a complex sport.

Future researchers under the same topic are advised to use more specific instruments to collect data.

\section{REFERENCES}

[1] Badruzaman, Metodik Beajar Renang. Bandung: FPOK UPI, 2007.

[2] G.D. Thomson, Renang Tingkat Mahir. Diterjemahkan oleh Alfons Palangkaraya, Jakarta: PT. Raja Grafindo Persada, 2000.

[3] K.P. Sari, Kontribusi Panjang Lengan, Kekuatan Tungkai Dan Kekuatan Otot Perut Terhadap Kecepatan Renang Gaya Kupu-Kupu Pada Atlet Renang Kota Makassar. Makassar, 2012.

[4] S. Murjoko, Hubungan Antara Tinggi Badan, Power Otot Lengan dan Power Otot Tungkai Terhadap Kecepatan Pembalikan Renang Gaya Dada, 2012

[5] B. Davis, Physical Education and the study of sport. 4th ed http://brianmac.com Spain: Harcourt. p. 124, 2000

[6] A. Palmer and R. Palmer, Torpedo School 2: Learn to Turn http://journal.crossfit.com, 2014.

[7] Harsono, Coaching dan Aspek-Aspek Psikologis dalam Coaching. Bandung: CV. Tambak Kusuma, 1988 